\title{
The impact of snow depth, snow density and ice density on sea ice thickness retrieval from satellite radar altimetry: results from the ESA-CCI Sea Ice ECV Project Round Robin Exercise
}

\author{
S. Kern ${ }^{1}$, K. Khvorostovsky ${ }^{2}$, H. Skourup ${ }^{3}$, E. Rinne ${ }^{4}$, Z. S. Parsakhoo ${ }^{1, *}$, V. Djepa ${ }^{5}$ P. Wadhams ${ }^{5}$ and S. Sandven $^{2}$ \\ ${ }^{1}$ Center for Climate System Analysis and Prediction CliSAP, University of Hamburg, Hamburg, Germany \\ ${ }^{2}$ Nansen Environmental and Remote Sensing Center NERSC, Bergen, Norway \\ ${ }^{3}$ Danish Technical University-Space, Copenhagen, Denmark \\ ${ }^{4}$ Finnish Meteorological Institute FMI, Helsinki, Finland \\ ${ }^{5}$ University of Cambridge, Cambridge, UK \\ *now at: Institute for Meteorology and Geophysics, University of Cologne, \\ Cologne, Germany
}

Correspondence to: S. Kern (stefan.kern@zmaw.de)

Received: 7 February 2014 - Published in The Cryosphere Discuss.: 7 March 2014

Revised: 9 October 2014 - Accepted: 5 November 2014 - Published: 6 January 2015

\begin{abstract}
We assess different methods and input parameters, namely snow depth, snow density and ice density, used in freeboard-to-thickness conversion of Arctic sea ice. This conversion is an important part of sea ice thickness retrieval from spaceborne altimetry. A data base is created comprising sea ice freeboard derived from satellite radar altimetry between 1993 and 2012 and co-locate observations of total (sea ice + snow) and sea ice freeboard from the Operation Ice Bridge (OIB) and CryoSat Validation Experiment (CryoVEx) airborne campaigns, of sea ice draft from moored and submarine upward looking sonar (ULS), and of snow depth from OIB campaigns, Advanced Microwave Scanning Radiometer (AMSR-E) and the Warren climatology (Warren et al., 1999). We compare the different data sets in spatiotemporal scales where satellite radar altimetry yields meaningful results. An inter-comparison of the snow depth data sets emphasizes the limited usefulness of Warren climatology snow depth for freeboard-to-thickness conversion under current Arctic Ocean conditions reported in other studies. We test different freeboard-to-thickness and freeboard-to-draft conversion approaches. The mean observed ULS sea ice draft agrees with the mean sea ice draft derived from radar altimetry within the uncertainty bounds of the data sets involved. However, none of the approaches are able to reproduce the seasonal cycle in sea ice draft observed by moored ULS. A
\end{abstract}

sensitivity analysis of the freeboard-to-thickness conversion suggests that sea ice density is as important as snow depth.

\section{Introduction}

As part of the European Space Agency (ESA) Climate Change Initiative (CCI) Sea Ice Essential Climate Variable (ECV) project (SICCI project), quality-controlled long-term data sets of sea ice thickness and concentration will be derived from Earth observation data. The product of sea ice thickness and sea ice area is the sea ice volume which is considered to be among the most sensitive indicators of the amplification of climate change in the Arctic (Schweiger et al., 2011; Zhang et al., 2012; Krinner et al., 2010; Stranne and Björk, 2012; Wadhams et al., 2012).

The main data source for hemispheric sea ice thickness distribution is satellite radar altimetry. Laxon et al. (2003) used European Remote Sensing Satellites (ERS1/2) radar altimeter (RA) data to obtain a first estimate of the sea ice thickness distribution in the Arctic Ocean south of $81.5^{\circ} \mathrm{N}$. More recently, Envisat and CryoSat-2 RA data has been used to compute sea ice thickness (Giles et al., 2008; Laxon et al., 2013); the northern limit for Envisat RA data is also $81.5^{\circ} \mathrm{N}$, while CryoSat-2 allows sea ice thickness retrieval 
up to $88^{\circ} \mathrm{N}$. In a number of studies, the retrieved sea ice freeboard and its derived thickness product were evaluated (e.g. Laxon et al., 2003; Giles and Hvidegaard, 2006; Giles et al., 2007; Connor et al., 2009). Yet to be calculated and evaluated is the sea ice thickness using the combined time series of ERS-1/2 RA data and Environmental Satellite (Envisat) radar altimeter-2 (RA-2) data of the period 1993 to 2012.

Sea ice thickness can be obtained with other methods than radar altimetry. The first Ice Cloud and Elevation Satellite (ICESat-1) with its Geoscience Laser Altimeter System (GLAS) allowed computing sea ice thickness from laser altimetry for up to three periods each year of about 1 month duration for years 2003 to 2009 (Kwok et al., 2009). Methods using spaceborne active or passive microwave sensor data (e.g. Kwok et al., 1995; Martin et al., 2004; Kaleschke et al., 2012) or using spaceborne infrared sensor data (e.g. Yu and Rothrock, 1996) do not allow computation of an Arctic-wide sea ice thickness distribution. These methods are limited in the maximum thickness to be retrieved, which is less than a metre, and can additionally be hampered by clouds. Also, satellite laser altimetry is influenced by clouds.

Ground-based, submarine-based, moored and airborne sensors provide sea ice thickness information via measurement of sea ice freeboard or thicknessor total (sea ice plus snow) freeboard or sea ice draft. Such data form the basis of our current understanding of Arctic Ocean sea ice volume loss (Rothrock et al., 2008; Lindsay, 2010; Haas et al., 2008, 2010; Schweiger et al., 2011, Wadhams et al., 2011). On the one hand this data has limited spatio-temporal coverage in contrast to satellite remote sensing data. On the other hand this data is extremely valuable for validation of sea ice thickness products obtained from satellite observations.

In order to derive sea ice thickness for all methods mentioned in the previous three paragraphs, assumptions need to be made about, e.g. ice and snow density, vertical sea ice structure, location of the dynamic sea surface height, and snow depth distribution. In addition to these, the RA method must also assume the penetration depth of radar waves into the snow. The only direct sea ice thickness measurement is a drill hole. Therefore it is important to keep in mind that products of the above-mentioned sources might have a bias and do have a finite uncertainty.

Within the SICCI project, a selection of the most suitable retrieval methods and the most appropriate input data sets for freeboard-to-thickness conversion using RA data is carried out in the so-called Round Robin Exercise (RRE). The RRE is based on analysis of data compiled in the Round Robin Data Package (RRDP). The RRDP comprises ERS$1 / 2$ and Envisat RA sea ice freeboard data, input data for the freeboard-to-thickness conversion and validation data of sea ice thickness, freeboard, draft, snow depth and total freeboard. The main goal is to find an optimal set of assumptions and input data for the freeboard-to-thickness conversion - assuming that the RA sea ice freeboard is correct. To do this, we investigate the quality of the data used and estimate the sensitivity of the methods used to the input parameters. Validation of RA sea ice freeboard and thickness data will be carried out at a later stage of the SICCI project. This is the reason why a number of data sets one would expect to be used in this study are not used. The amount of sea ice thickness data is limited and we could not use the same data in algorithm selection and validation. We chose to save the sea ice thickness derived from ICESat-1 measurements (Kwok et al., 2009), the total (sea ice + snow) thickness derived from electromagnetic (EM) induction sounding (Haas et al., 2008, 2010) and data from recent (2011 to the present) Operation Ice Bridge (OIB) campaigns for the validation exercise.

The paper is organized as follows. Section 2 describes the RRDP. Section 3 describes the methods used. In Sect. 4, we present the results of our analyses. These are discussed in Sect. 5 and concluded in Sect. 6. We note that the results presented reflect the work of the SICCI project consortium and have been carried out at the respective institutions.

\section{Data}

The RRDP comprises satellite data: ERS-1/2 RA and Envisat RA-2 sea ice freeboard and snow depth from Advanced Microwave Scanning Radiometer aboard Earth Observation Satellite (AMSR-E). The RRDP includes snow depth and density data from the Warren climatology (Warren et al., 1999), henceforth abbreviated with W99, and it includes a variety of sea ice data from other platforms. These are basically data from moored, submarine and airborne sensors as listed in Table 1. All data will be described in the following paragraphs. Figure 1 shows a sample Envisat RA-2 sea ice freeboard map for March 2010 together with the locations where these other data are taken from. The majority of RA-2 sea ice freeboard values are in a reasonable range (between $0.1 \mathrm{~m}$ and $0.4 \mathrm{~m}$ ).

Sea ice freeboard data as used in the RRDP are derived from ERS-1/2 RA and Envisat RA-2 data using the methodology introduced by Laxon et al. (2003) and Giles et al. (2008) and described in detail in the SICCI ATBD (ESA SICCI project consortium, 2013). To shortly recap, elevation measurements from leads and ice floes are distinguished based on the pulse peakiness of the waveform. After re-tracking the range and applying necessary corrections (namely the Doppler range and delta Doppler, the ionospheric, the dry tropospheric and the modelled wet tropospheric, ocean tide, long-period tide, loading tide, earth tide, pole tide and inverse barometer corrections) and filters (removal of complex waveforms, failed re-tracking and echoes that yielded elevations more than $2 \mathrm{~m}$ from the mean dynamic sea surface height), the local sea level at ice floe locations is interpolated from nearby lead elevations. Freeboard is then calculated as the difference of radar-altimetry-measured ice floe elevation and the local sea level. Individual radar altimeter freeboard measurements are present in the RRDP data 
Table 1. Validation data used in the RRDP for sea ice thickness.

\begin{tabular}{lllll}
\hline Date & Location & Parameter & Source & Acronym \\
\hline 2003-2008 & Beaufort Sea & Ice draft, snow depth & BGEP moored ULS, AMSR-E & BGEP \\
\hline $\begin{array}{l}\text { Apr 1994 } \\
\text { Oct 1996 }\end{array}$ & Beaufort Sea & Ice draft & NSIDC US submarine ULS & BS \\
\hline Mar 2007 & Fram Strait, & Ice draft, snow depth & UCAM UK submarine ULS, AMSR-E & BSS \\
\hline $\begin{array}{l}\text { May 2011 } \\
\text { Apr 2008 }\end{array}$ & Fram Strait & Ice freeboard, thickness, snow depth & DTU ALS, ASIRAS, AMSR-E & FS \\
\hline Oct 2009 & Western Arctic & Ice freeboard, thickness, snow depth & NSIDC IceBridge & OIB \\
\hline
\end{tabular}

base. These measurements correspond to the freeboard of ice within the surface footprint of the altimeter. The size of the footprint, i.e. the spatial resolution of the instrument, depends on the target surface properties and is of the order of 2 to $10 \mathrm{~km}$ (Connor et al., 2009).

The net uncertainty of the gridded RA-derived freeboards is unknown. The factors contributing to the freeboard uncertainty include sub-footprint surface roughness, ambiguities in radar penetration into snow, bias due to wave shape from leads and floes, tides, the uncertainty in satellite position and radar speckle. Due to the speckle a large number of RA freeboard estimates must be averaged to get a meaningful estimate. In this work individual RA freeboard estimates are averaged according to the collocation areas defined in Sect. 2 further below, or into a $2^{\circ}$ longitude $\times 0.5^{\circ}$ latitude grid (approximately $60 \mathrm{~km}$ grid cell size). Averaging is always done over 1 calendar month. Depending on latitude and number of leads identified this results hardly in more than 200 measurements per grid cell to be averaged for the gridded product. This is illustrated in Fig. 2 showing for months October to March the average number $N$ of single orbit Envisat RA-2 sea ice freeboard data used per month per $100 \mathrm{~km}$ grid cell which is the grid resolution of the SICCI project SIT prototype product. Averaging is done over the entire Envisat RA2 period, i.e. winters $2002 / 03$ to $2011 / 12$. Note the decline in areas with $N>200$ over the season (compare November to March) in the northern Beaufort and Chukchi Seas. This can be most likely attributed to a smaller number of leads as shown by Bröhan and Kaleschke (2014).

In this paper we do not discuss the uncertainty of RA freeboards. This will be done later as part of the Sea Ice CCI validation exercise. Instead we take the freeboard estimates as accurate and study the effect of using different assumptions about the sea ice and snow density as well as different sources of snow depth estimates.

W99 snow depth and density data is available as climatological monthly values for a given location of the Arctic Ocean. Because the W99 climatology is a second-degree polynomial decreasing rapidly outside the central Arctic Ocean (Warren et al., 1999), extrapolated estimates, e.g. in

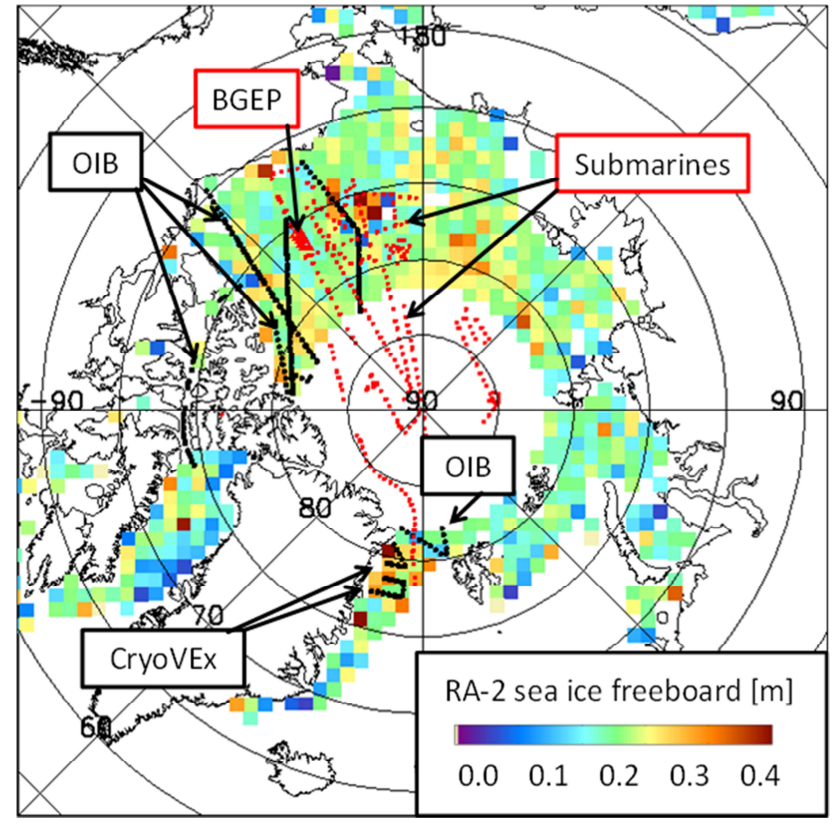

Figure 1. Envisat RA-2 sea ice freeboard distribution for March 2010 superposed with locations of campaigns used for our intercomparison study: airborne campaigns (in black): CryoVEx, OIB; moored and submarine upward looking sonar (ULS) in red: BGEP, Submarines. Grid resolution is $100 \mathrm{~km}$. The white circular area around the pole indicates the region north of the $81.5^{\circ} \mathrm{N}$ parallel with no Envisat RA-2 data.

the Hudson Bay or the Bering Sea, should not be taken as real snow depth values. W99 data can be considered reliable up to the coasts on the Pacific and Eurasian side of the Arctic Ocean. Towards the Atlantic side the approximate southern limit of useful W99 data is $80^{\circ} \mathrm{N}$ (Warren et al., 1999); south of this latitude no or only few observations contributed to the climatology. W99 snow depth and density data are collocated individually for each single RA freeboard estimate and averaged over the same area and time as the freeboard (see above paragraph and Sect. 2 further below). 


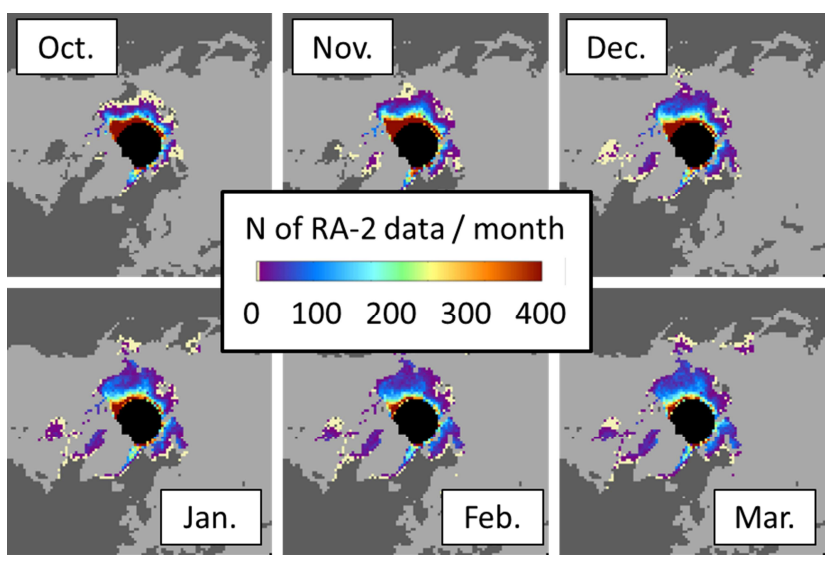

Figure 2. Average number $\mathrm{N}$ of Envisat RA-2 data per $100 \mathrm{~km}$ grid cell per month for the period 2002/03 to 2011/12.

AMSR-E snow depth on sea ice is taken for the Arctic from the AMSR-E/Aqua Daily L3 $12.5 \mathrm{~km}$ Brightness Temperature, Sea Ice Concentration, \& Snow Depth Polar Grids product (http://nsidc.org/data/docs/daac/ae_si12_ 12km_tb_sea_ice_and_snow.gd.html, Cavalieri et al., 2004) available from NSIDC. These data are provided daily at $12.5 \mathrm{~km}$ grid resolution as running 5-day means and are limited to snow depths below $0.45 \mathrm{~m}$ on seasonal ice (Markus and Cavalieri, 1998; Comiso et al., 2003). The algorithm is sensitive to sea ice roughness (Worby et al., 2008, OzsoyCicek et al., 2011; Kern et al., 2011) as well as snow wetness and grain size (Maksym and Markus, 2008; Markus and Cavalieri, 1998). Recently, the quality of AMSR-E snow depth was assessed for the Arctic (Cavalieri et al., 2012; Brucker and Markus, 2013). A comparison between OIB and AMSRE snow depths for about six hundred $12.5 \mathrm{~km}$ grid cells from the years 2009 to 2011 (Brucker and Markus, 2013) indicated a basin average bias of up to $0.07 \mathrm{~m}$ and RMSD values between $0.03 \mathrm{~m}$ and $0.15 \mathrm{~m}$. Under ideal conditions, i.e. for high concentration (>90\%) level first-year ice (FYI) thicker than $0.5 \mathrm{~m}$, the RMSD is below $0.06 \mathrm{~m}$ for, on average, $0.2 \mathrm{~m}$ thick snow (Brucker and Markus, 2013). For our study, AMSR-E snow depth is collocated with RA sea ice freeboard by averaging data over a calendar month over a disc of $100 \mathrm{~km}$ radius centred at each RA sea ice freeboard grid cell.

The combination of a laser scanner and snow radar or a radar altimeter provides simultaneous collocated snow depth, total (sea ice + snow) freeboard and sea ice freeboard data. The laser scanner senses the snow surface and is used to derive the total freeboard - similar to the ICESat-1 GLAS instrument - if the instantaneous sea surface height ( $\mathrm{SSH})$ is known. The snow radar directly measures snow depth on top of sea ice using the range difference between reflections at the two interfaces, ice-snow and snow-air. For a radar altimeter operating at $\mathrm{Ku}$-band frequencies it is assumed that it provides the height of the ice-snow interface above the SSH: the sea ice freeboard, under dry snow and/or freezing conditions.

The RRDP includes a combination of CryoVEx laser scanner (ALS) and radar altimeter data (ASIRAS). ALS and ASIRAS data are taken from DTU Space, National Space Institute (ftp://ftp2.spacecenter.dk/pub/ESACCI-SI/) and are averaged over $50 \mathrm{~km}$ transects of flight line (see Fig. 1 for location). We use CryoVEx data from campaigns at the end of April 2008 and beginning of May 2011. The collocated RA-2 data are averages for April of the respective year of observation from all orbits within a disc of $100 \mathrm{~km}$ radius centred at each ALS $50 \mathrm{~km}$ transect centre. ALS data are used to derive total freeboard (Hvidegaard and Forsberg, 2002) with accuracy and precision of independent measurements of about $0.1 \mathrm{~m}$ to $0.15 \mathrm{~m}$. ASIRAS sea ice freeboard data are derived using a method similar to Ricker et al. (2012) and have an accuracy of $0.15 \mathrm{~m}$ to $0.2 \mathrm{~m}$ for independent measurements. As measurements are averaged along $50 \mathrm{~km}$ transects located in an area of frequent lead occurrence the accuracy relevant for this study is of the order of $0.01 \mathrm{~m}$ for the ALS data. For the same reason it can be expected that the accuracy of the ASIRAS data is better than the numbers given above and has a magnitude of $0.05 \mathrm{~m}$ to $0.1 \mathrm{~m}$.

We note that the radius of $100 \mathrm{~km}$ seems to be quite large. We have demonstrated, though, that a month of averaging over single orbit RA-2 sea ice freeboard data and hence using a large number of data points per grid cell (Fig. 2) is required for a sufficient reduction of particularly speckle noise. Using a smaller radius of, for example, $50 \mathrm{~km}$ would reduce the number of data points per averaging area substantially. In addition, airborne campaign data are usually for only a few days and are therefore a snapshot compared to the RA-2 data averaging period of a calendar month. The sea ice sensed during the airborne campaign might have drifted out of the collocation area around the transect centre used if a too small collocation area had been chosen. Hence, for all collocations with airborne or submarine-based data, we used a collocation area radius of $100 \mathrm{~km}$.

The RRDP includes OIB laser scanner (Airborne Thematic Mapper, ATM)-measured and snow radar-measured total freeboard, snow depth, and ice thickness (Panzer et al., 2013; Kurtz et al., 2013). OIB data are taken from the NSIDC (http://nsidc.org/data/icebridge/index.html) and are averaged over $50 \mathrm{~km}$ transects along track. The collocated RA-2 data are monthly averages of observations from all orbits within a disc of $100 \mathrm{~km}$ radius centred at each OIB $50 \mathrm{~km}$ transect centre. We used data from OIB campaigns in April 2009 and March and April 2010 (see Fig. 1 for location). Kurtz et al. (2013) summarize the uncertainty sources of OIB snow depth retrieval. They point out that the results of Farrell et al. (2012) are a bit too optimistic $(0.01 \mathrm{~m}$ uncertainty in snow depth) and instead suggest a snow depth uncertainty of $0.06 \mathrm{~m}$ in agreement with Kwok et al. (2011): $0.03 \mathrm{~m}$ to $0.05 \mathrm{~m}$ for snow depths between $0.1 \mathrm{~m}$ and $0.7 \mathrm{~m}$. Lowest re- 
trievable snow depth is of the magnitude $0.05 \mathrm{~m}$ (see also Kwok and Maksym, 2014).

In addition to snow depth, the OIB freeboards are shown to be accurate. Past problems identified with the automatic SSH retrieval from ATM data alone for 2009 (Nathan Kurtz, personal communication, 2013) were mitigated starting with the 2010 OIB data by including contemporary digital imagery (Onana et al., 2013). For the bulk of total freeboard obtained from OIB ATM measurements, the bias can be expected to be close to zero, with a precision of between $0.05 \mathrm{~m}$ and $0.1 \mathrm{~m}$ (Farrell et al., 2012; Kurtz et al., 2013). This is confirmed by a study of Kwok et al. (2012), who found agreement between ICESat-1 and OIB-ATM freeboards of within $0.01 \mathrm{~m}$ and a measurement repeatability of about $0.04 \mathrm{~m}$.

Upward looking sonar (ULS) observes sea ice draft which can be converted into sea ice thickness in a similar way as the sea ice freeboard. In the RRDP we use data from the Beaufort Gyre Exploration Project (BGEP) where three, sometimes four, moored ULS measured sea ice draft. The approximate location of these moorings is denoted by the red triangles in Fig. 1. BGEP ULS data are taken for years 2003 to 2008 from WHOI (http://www.whoi.edu/page.do? pid=66559). Accuracy of the data is between $0.05 \mathrm{~m}$ and $0.1 \mathrm{~m}$ (Krishfield and Proshutinsky, 2006). This data provides an independent measure of the seasonal cycle of sea ice draft and thus sea ice thickness. The collocated data are monthly averages of observations from all single orbit RA-2 sea ice freeboards which fall into a box centred at the BGEP mooring location (see Fig. 1) extending over 12 degree latitude and 30 degree longitude. Snow depth data are averaged over the same area. This box may be oversized. The rationale behind using such a large co-location area was to maximize the number of valid RA freeboard estimates and to minimize the effect of sea ice motion changing ice type composition in that area.

Another source of ULS data in the RRDP are those carried on board submarines. Submarine ULS draft data were successfully used by Laxon et al. (2003) for a first assessment of Arctic Ocean sea ice thickness distribution obtained from ERS-1/2 data. The RRDP contains submarine ULS data from three cruises (red dots in Fig. 1). Data from two of the cruises from US submarines (April 1994 and October 1996) are available from NSIDC (http://nsidc.org/data/g01360.html). Data from the third cruise by a UK submarine (March/April 2007) are available from University of Cambridge (UCAM), see also (Wadhams et al., 2011). Submarine ULS data are in general less accurate than the BGEP data but are the only information about draft distribution over a larger region. Rothrock and Wensnahan (2007) report a bias of $0.29 \mathrm{~m}$ and a standard deviation of $0.25 \mathrm{~m}$. An assessment of the UK submarine ULS data used reveals a standard deviation of $0.29 \mathrm{~m}$ and a bias of $0.4 \mathrm{~m}$; these numbers are worse compared to the US submarine data due to classified submarine positions. The collocated RA-2 data are monthly averages of observations from all orbits within a disc of $100 \mathrm{~km}$ radius centred at each

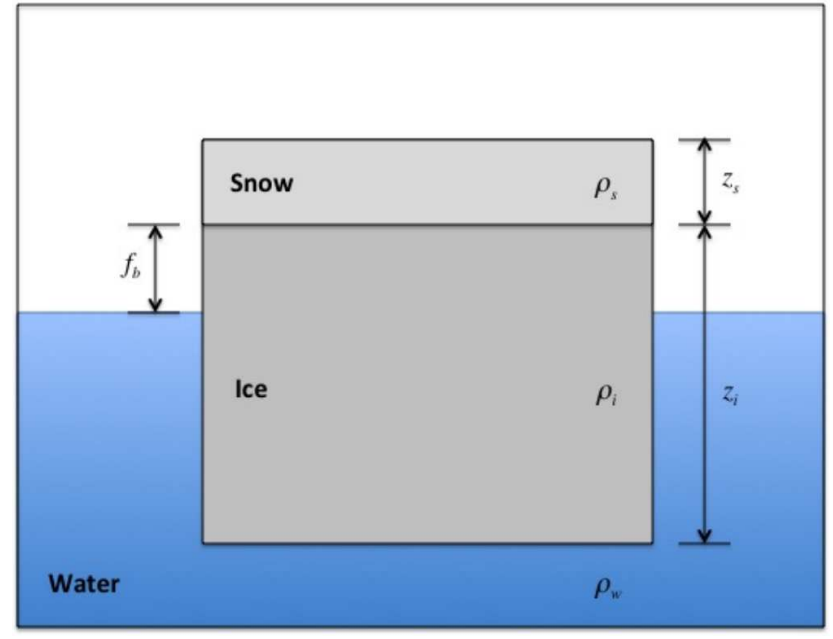

Figure 3. Illustration of the parameters involved in sea ice thickness computation using sea ice freeboard.

submarine ULS $50 \mathrm{~km}$ transect centre. A transect length of $50 \mathrm{~km}$ is recommended by Rothrock and Wensnahan (2007).

\section{Methods}

It is assumed that satellite radar altimetry measures the sea ice freeboard. By assuming isostasy, sea ice freeboard can be used to compute sea ice thickness $z_{i}$ :

$z_{i}=\frac{z_{\mathrm{s}} \rho_{\mathrm{s}}+f_{\mathrm{b}} \rho_{\mathrm{w}}}{\rho_{\mathrm{w}}-\rho_{i}}$

and also sea ice draft $D$

$D=\frac{z_{s} \rho_{s}+f_{b} \rho_{i}}{\rho_{w}-\rho_{i}}$,

with snow depth $z_{s}$, sea ice freeboard $f_{b}$, and the densities of sea water, sea ice and snow: $\rho_{w}, \rho_{i}$, and $\rho_{s}$, respectively. Figure 3 illustrates the parameters used in Eq. (1).

The main objectives of the Round Robin Exercise are

- to select the best snow depth (product) for freeboard-tothickness conversion

- to investigate the validity and influence of retrieval assumptions, such as using constant sea ice density, on the sea ice thickness retrieval

In order to achieve these goals, the following investigations are carried out:

1. Snow depth data of the different data sets involved are inter-compared.

2. RA-2 sea ice freeboard is converted to total freeboard by adding snow depth information and compared with OIB and CryoVEx total freeboard. 
3. RA and RA-2 sea ice freeboard is used to compute sea ice draft $D$ using Eq. (2) with different input data and compared to ULS sea ice draft data. This is done using a "standard set of densities" (see below). For BGEP mooring ULS data, we additionally compute sea ice draft separately for multiyear ice (MYI) and FYI densities and two different fixed snow densities.

4. RA-2 sea ice freeboard is used to compute sea ice thickness combining the standard set of densities with various snow depth information; the results are compared to OIB sea ice thickness.

The standard set of densities is $\rho_{i}=900 \mathrm{~kg} \mathrm{~m}^{-3}$, which is the average density of MYI and FYI, and $\rho_{w}=1030 \mathrm{~kg} \mathrm{~m}^{-3}$ (Wadhams et al., 1992). The snow density is taken from W99 and varies over space and time. In order to account for the effect of different densities for MYI and FYI (in investigation 3, see above), we use sea ice densities published elsewhere (e.g. Timco and Frederking, 1996; Alexandrov et al., 2010): $882 \mathrm{~kg} \mathrm{~m}^{-3}$ and $917 \mathrm{~kg} \mathrm{~m}^{-3}$, respectively. The two fixed snow density values used in investigation 3 (see above) are $240 \mathrm{~kg} \mathrm{~m}^{-3}$ and $340 \mathrm{~kg} \mathrm{~m}^{-3}$ and correspond to the mean wintertime minimum and maximum snow density, respectively (Warren et al., 1999).

\section{Results}

In the following we present the results of comparing the various data sets. We start with snow depth and (sea ice) freeboard and then continue with sea ice draft and thickness.

\subsection{Snow depth}

The results of the inter-comparison of collocated W99, OIB and AMSR-E are summarized for 2009 and 2010 in Table 2. OIB data from the Arctic Ocean, the Canadian Archipelago, and the Fram Strait region are used (see Fig. 1). Mean snow depth along the OIB tracks in the Arctic Ocean in 2009 is $0.36 \mathrm{~m}$ and $0.16 \mathrm{~m}$ over MYI and FYI, respectively. In 2010, OIB snow depth is $0.23 \mathrm{~m}$ and $0.13 \mathrm{~m}$ over MYI and FYI, respectively. Over MYI, OIB and W99 snow depths agree within $0.02 \mathrm{~m}$ in 2009 while in 2010 W99 overestimates OIB snow depth by $0.12 \mathrm{~m}$. Over FYI, W99 overestimates OIB snow depths by $0.19 \mathrm{~m}$ and $0.21 \mathrm{~m}$ in 2009 and 2010, respectively. In April 2010, OIB flights tracks are located over FYI in the Arctic Ocean and in the Canadian Archipelago. For the latter region, we found a similar mean snow depth over FYI than in the Arctic Ocean. We did not compare OIB and W99 snow depths because in the Canadian Archipelago, W99 snow depth relies purely on extrapolation (Warren et al., 1999). In April 2010, OIB flight tracks covered the Fram Strait area (Fig. 1). These tracks also are north of $80^{\circ} \mathrm{N}$ and thus still in the region of valid W99 snow depth data. W99 overestimation of OIB snow depth is even larger than for
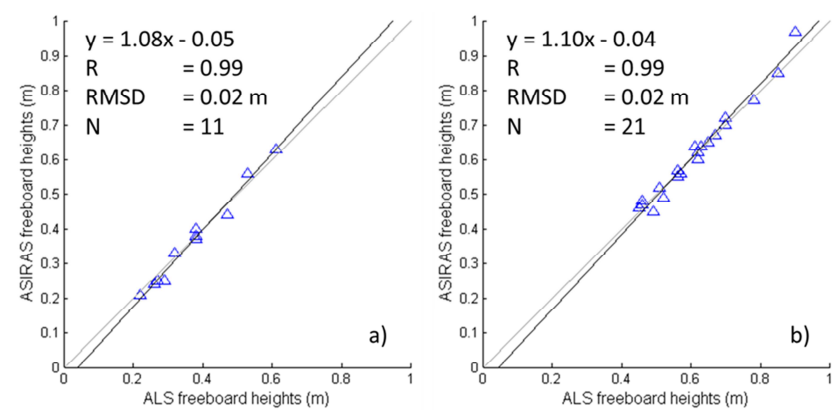

Figure 4. Scatterplot ASIRAS versus ALS total freeboard for the CryoVEx campaigns (see Fig. 1 for location) in 2008 (a) and 2011 (b).

the tracks in the Arctic Ocean. W99 snow depth is about $0.40 \mathrm{~m}$ while the mean snow depth along the OIB track is $0.17 \mathrm{~m}$. In both years, 2009 and 2010, W99 snow depths are about twice as large as AMSR-E snow depth over FYI in the Arctic Ocean. The difference is $0.18 \mathrm{~m}$ (Table 2), which is of the same magnitude as the difference between OIB and W99 snow depth (see previous paragraph). AMSR-E and OIB snow depths agree on average by about $0.02 \mathrm{~m}$ for the flight tracks crossing the Arctic Ocean as well as those in the Canadian Archipelago. For the OIB flight in the Fram Strait region, none of the collocation regions contained enough FYI for a comparison between AMSR-E and OIB snow depths.

The results of our snow depth comparison agree with Kurtz and Farrell (2011) and Kurtz et al. (2013): over FYI AMSR-E data give a much better measure of the actual snow depth than W99. Snow depths from W99 are about twice as large as AMSR-E and OIB snow depths over FYI. Over MYI, OIB and W99 differ by only $0.02 \mathrm{~m}$ in 2009 but by $0.12 \mathrm{~m}$ in 2010. Only grid cells with at least $65 \%$ MYI are used here. One possible explanation for the different degree of agreement could be inter-annual variation in snow depth over MYI. While in 2009 OIB snow depth was $0.36 \mathrm{~m}$ it was just $0.23 \mathrm{~m}$ in 2010 . Mean W99 snow depth was $0.35 \mathrm{~m}$ and $0.34 \mathrm{~m}$, respectively. Based on climatology, the W99 does not capture the inter-annual variability in snow depth. The W99 estimate for inter-annual variability for the snow depth in March is $0.06 \mathrm{~m}$, explaining half of the observed difference in 2010.

\subsection{Sea ice and total freeboard}

During the CryoVEx campaigns in 2008 and 2011 in the Fram Strait, both the radar altimeter (ASIRAS) and the laser instrument (ALS) essentially sensed the snow surface as is illustrated in the scatterplots in Fig. 4. Radar penetration into the snow cover on sea ice in the Fram Strait during CryoVEx campaigns was close to zero although the radar is supposed to sense the ice-snow interface at the frequency used in Ku-band according to laboratory experiments (Beaven et al., 1995). There is growing evidence that this assumption is 
Table 2. Summary of the comparison between OIB, W99 and AMSR-E snow depth in the Arctic Ocean. Absolute values are only given for OIB; all other values are differences. All values are given together with one standard deviation.

\begin{tabular}{lllll}
\hline Data set & All & MYI $(>65 \%)$ & FYI $(>95 \%)$ & Can. Arch. \\
\hline OIB 2009 & $(0.26 \pm 0.11) \mathrm{m}$ & $(0.36 \pm 0.04) \mathrm{m}$ & $(0.16 \pm 0.02) \mathrm{m}$ & - \\
OIB - W99 & $(-0.07 \pm 0.11) \mathrm{m}$ & $(0.02 \pm 0.04) \mathrm{m}$ & $(-0.19 \pm 0.02) \mathrm{m}$ & - \\
OIB - AMSR-E & - & - & $(-0.01 \pm 0.02) \mathrm{m}$ & - \\
W99 - AMSR-E & - & - & $(0.18 \pm 0.03) \mathrm{m}$ & - \\
OIB 2010 & $(0.21 \pm 0.07) \mathrm{m}$ & $(0.23 \pm 0.05) \mathrm{m}$ & $(0.13 \pm 0.02) \mathrm{m}$ & $(0.13 \pm 0.04) \mathrm{m}$ \\
OIB - W99 & $(-0.13 \pm 0.07) \mathrm{m}$ & $(-0.12 \pm 0.05) \mathrm{m}$ & $(-0.21 \pm 0.01) \mathrm{m}$ & - \\
OIB - AMSR-E & - & - & $(-0.03 \pm 0.02) \mathrm{m}$ & $(-0.01 \pm 0.03) \mathrm{m}$ \\
W99 - AMSR-E & - & - & $(0.18 \pm 0.02) \mathrm{m}$ & - \\
\hline
\end{tabular}

violated for more cases than previously thought (e.g. Ricker et al., 2014). Both freeboard measurements (ASIRAS and ALS) linearly agreed with a RMSD of $0.02 \mathrm{~m}$, a bias of about $0.05 \mathrm{~m}$, a slope close to 1 and a linear correlation coefficient of 0.99 for 2008 and 2011. Therefore from CryoVEx, only total freeboard is used in this study.

For 2011, CryoVEx ALS total freeboard underestimates RA-2 total freeboard computed using W99 snow depth by $0.06 \mathrm{~m}$; for 2008 , this underestimation is about $0.16 \mathrm{~m}$. These values are larger than the uncertainties expected for transect lengths of $50 \mathrm{~km}$ for the ALS data. It has to be kept in mind that we look at only 11 and 21 data pairs in 2008 and 2011, respectively. During CryoVEx 2008, the sea ice in the measured area was primarily FYI, and by applying snow depth from AMSR-E (available for 9 out of 11 points) the comparison of total freeboards is improved. In addition both CryoVEx campaigns are south of $80^{\circ} \mathrm{N}$, where W99 is solely based on extrapolation and is hence not very reliable.

OIB total freeboard observations of 2009 and 2010 are compared with RA-2 total freeboards computed from collocated RA-2 sea ice freeboard by adding the respective collocated OIB or W99 snow depth in the Arctic Ocean (Table 3, Fig. 5); observations in the Fram Strait and the Canadian Archipelago are excluded. Mean OIB total freeboard in the Arctic Ocean agrees overall within $0.02 \mathrm{~m}$ with RA-2 total freeboard when using collocated OIB snow depths. If instead W99 snow depth is used the agreement remains fine for 2009, but for 2010 RA-2 underestimates the overall mean OIB total freeboard by $0.11 \mathrm{~m}$. This could be explained by the difference between OIB snow depth and W99 snow depth (see Sect. 4.1). However, it could also be explained by the different fraction of MYI in these data sets. For 2009 the selected OIB flight tracks were located over MYI only, while in 2010 about one-third of the OIB data of the selected OIB tracks were located over FYI. As shown in Sect. 4.1, OIB snow depth agrees much better with W99 snow depth over MYI than over FYI.
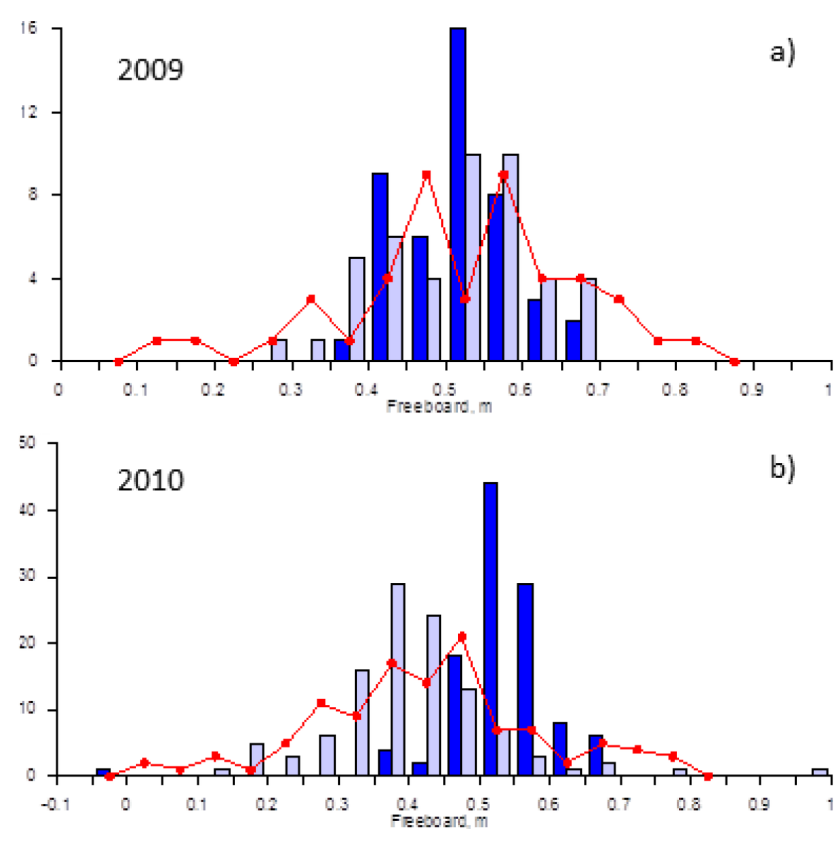

Figure 5. Histograms of OIB (red lines) and RA-2 (blue bars) freeboard for OIB data from the Arctic Ocean for 2009 (a) and 2010 (b). RA-2 freeboard is derived using OIB snow depth (light blue bars) and W99 snow depth (dark blue bars). Both MYI and FYI data are included. Note the different $y$ axis ranges for the number of data per freeboard bin.

\subsection{Sea ice draft}

The results of the comparison of sea ice draft between ULS and radar altimeter is summarized in Tables 4 and 5. Sea ice draft observed by US submarine ULS in October 1996 is overestimated by ERS-1 RA by $0.13 \mathrm{~m}$ which is within the ULS uncertainty of $0.25 \mathrm{~m}$ to $0.3 \mathrm{~m}$ (Table 4). For April 1994, however, ERS-1 RA underestimates observed sea ice draft by $0.45 \mathrm{~m}$ which is outside the uncertainty range given for these ULS data. This discrepancy is illustrated in Fig. 6c and d: while both data sets show maximum probability in the same draft bin of $1.5 \mathrm{~m}$ to $2.0 \mathrm{~m}$ for 1996 , the histograms are shifted relative to each other for April 1994 with largest 
Table 3. Summary of overall mean observed (OIB) and computed (RA-2) snow freeboard using OIB or W99 snow depth; given are mean values plus/minus one standard deviation.

\begin{tabular}{cccc}
\hline Data set & $\begin{array}{c}\text { Snow freeboard } \\
\text { (OIB) }\end{array}$ & $\begin{array}{c}\text { Snow freeboard } \\
\text { (RA-2 + OIB snow depth) }\end{array}$ & $\begin{array}{c}\text { Snow freeboard } \\
\text { (RA-2 + W99 snow depth) }\end{array}$ \\
\hline OIB 2009 & $(0.52 \pm 0.15) \mathrm{m}$ & $(0.51 \pm 0.10) \mathrm{m}$ & $(0.52 \pm 0.07) \mathrm{m}$ \\
OIB 2010 & $(0.42 \pm 0.16) \mathrm{m}$ & $(0.40 \pm 0.12) \mathrm{m}$ & $(0.53 \pm 0.08) \mathrm{m}$ \\
\hline
\end{tabular}
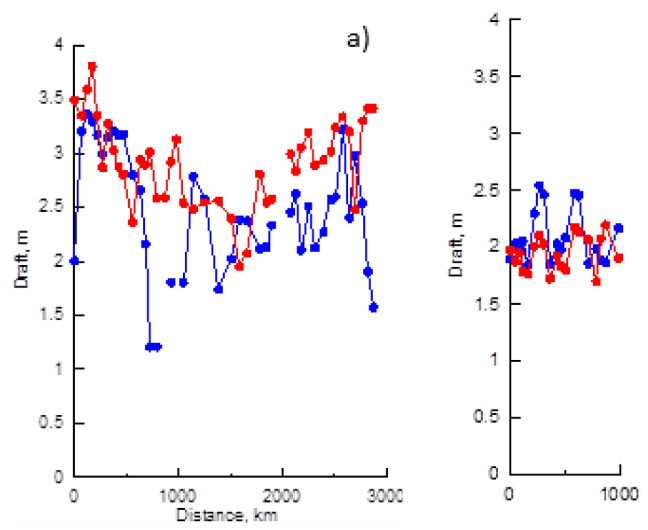

b)
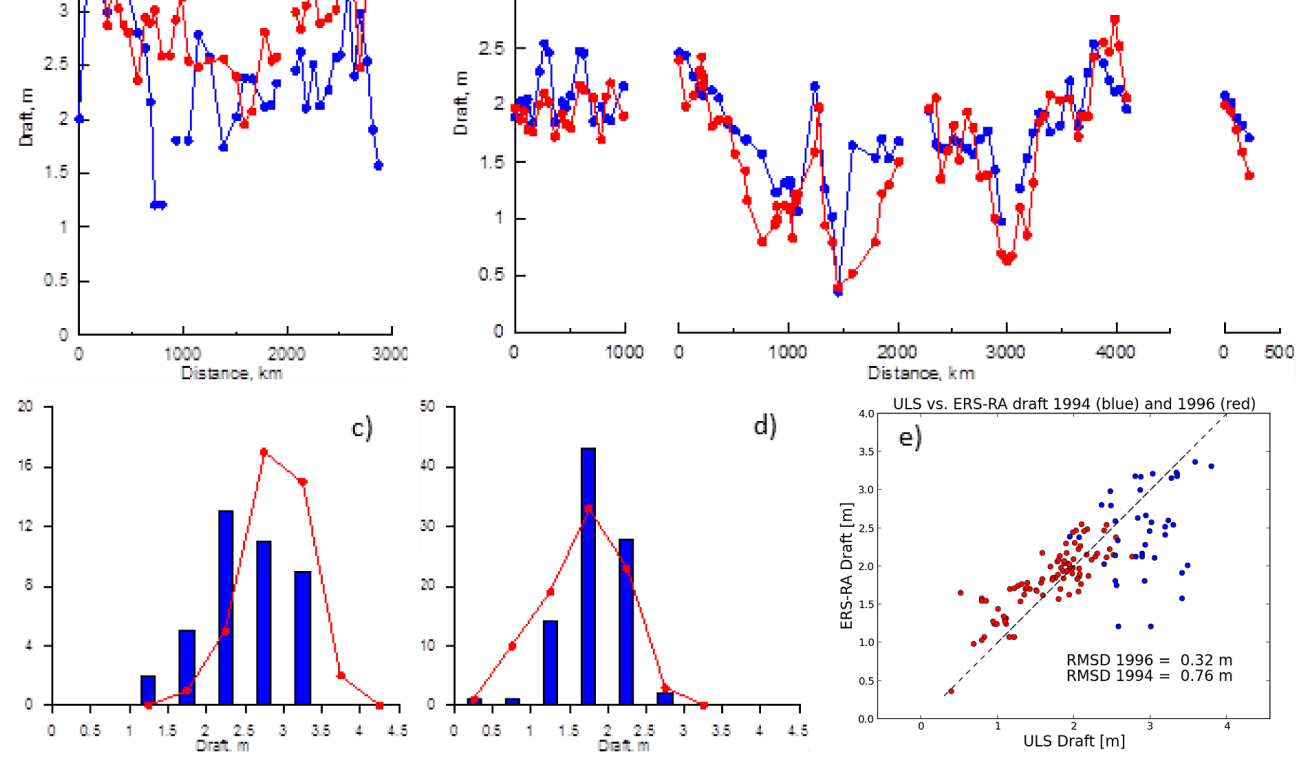

d)

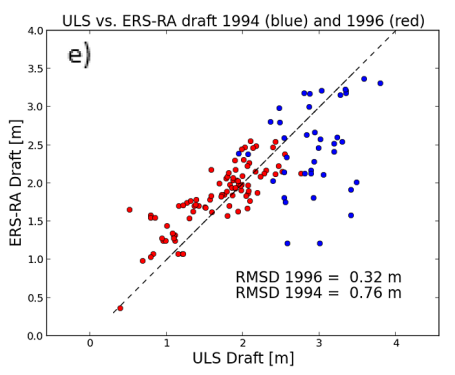

Figure 6. Comparison between sea ice draft observed from US submarine ULS (red) and computed from ERS-1 RA sea ice freeboard using W99 snow data (blue). Images (a) and (b) are profiles along submarine track for April 1994 and October 1996, respectively (see also Fig. 1); Images (c) and (d) show corresponding histograms; the $y$ axis denotes the number of data per draft bin. Image (e) compares data from both cruises for 1994 (blue) and 1996 (red) together with the RMSD.

probability in bin $2.5 \mathrm{~m}$ to $3.0 \mathrm{~m}$ for the ULS data but $2.0 \mathrm{~m}$ to $2.5 \mathrm{~m}$ for RA data. The scatterplot in Fig. 6e underlines that the agreement is much better for October 1996 than for April 1994; in particular the RMSD for 1996 is less than half that for 1994.

Sea ice draft observed by UK submarine ULS in April 2007 is underestimated by RA-2 by $0.12 \mathrm{~m}$ (Table 4). However, the majority of this cruise took place north of $81.5^{\circ} \mathrm{N}$ (see also Fig. 1) and our comparison is therefore based on only 15 collocated data pairs, compared to about 90 and 40 data pairs for the US submarine cruises.

Mean winter sea ice draft observed by BGEP ULS agrees within $0.05 \mathrm{~m}$ with sea ice draft computed from RA-2 data using W99 snow depth and density, and standard sea ice and water density values. However, the seasonal range in sea ice draft is much lower for RA-2 than for BGEP ULS (Table 4, Fig. 7). Only for winters 2005/2006 and 2006/2007 does the seasonal range of sea ice draft agree in both data sets. The area considered here was covered by almost $100 \%$ MYI from 2003 to 2007 (first four winters), whereas FYI entered the region in winter 2007/2008 (taken from AMSR-E snow depth data set, Cavalieri et al., 2004). Therefore, for the first four winters, one might need to use the MYI density instead of the value of $900 \mathrm{~kg} \mathrm{~m}^{-3}$ used. By doing so the RA-2 draft would decrease by between $0.1 \mathrm{~m}$ and $0.4 \mathrm{~m}$, depending on season and year (Fig. 7, brown lines). This would result in a better agreement between BGEP ULS and RA-2 draft early in the winter season, but it would not improve the agreement in terms of the seasonal range. A possible explanation for our RA2 drafts not showing the same seasonal range as ULS drafts could be that during winter more new ice forms and thus the net ice density increases. Confirming this would however require direct ice density measurements. Note that usage of AMSR-E snow depth, possible for winter 2007/2008, results in RA-2 ice draft values that would be typical for $100 \%$ MYI and a snow density of about 
Table 4. Summary of observed and computed sea ice draft values using standard settings and W99 snow parameters; given are mean values plus/minus one standard deviation. The respective month the data set is valid for is given in the first column. See Table 1 for data set acronyms.

\begin{tabular}{lcc}
\hline Data set & Observed draft (ULS) & Derived draft (RA, RA-2) \\
\hline BS 1994 (April) & $(2.92 \pm 0.41) \mathrm{m}$ & $(2.47 \pm 0.57) \mathrm{m}$ \\
BS 1996 (October) & $(1.68 \pm 0.51) \mathrm{m}$ & $(1.81 \pm 0.41) \mathrm{m}$ \\
BSS 2007 (March) & $(2.48 \pm 0.46) \mathrm{m}$ & $(2.36 \pm 0.54) \mathrm{m}$ \\
BGEP 2003-2008 & $(1.59 \pm 0.42) \mathrm{m}$ & $(1.64 \pm 0.25) \mathrm{m}$ \\
(October to March) & & \\
\hline
\end{tabular}

Table 5. Differences of mean and median observed minus computed sea ice draft from submarine and moored ULS (see Table 1) and algorithms A1 to A6 applied to radar altimeter data for the Arctic Ocean. Algorithms giving the smallest difference are highlighted in bold.

\begin{tabular}{llllllll}
\hline & Data set & A1 & A2 & A3 & A4 & A5 & A6 \\
& BS, & 0.13 & -0.12 & 0.06 & 0.13 & 0.49 & $\mathbf{0 . 0 1}$ \\
& $10 / 1996$ & $\mathbf{( 0 . 0 3 )}$ & $(-0.23)$ & $(0.04)$ & $(\mathbf{0 . 0 3})$ & $(0.35)$ & $(-0.13)$ \\
\cline { 2 - 7 } Difference & BGEP, & $\mathbf{- 0 . 0 1}$ & -0.22 & 0.02 & -0.04 & 0.16 & -0.43 \\
in mean & $2002 / 03$ & $\mathbf{( 0 . 0 5})$ & $(-0.19)$ & $(0.09)$ & $(\mathbf{0 . 0 5})$ & $(0.27)$ & $(-0.35)$ \\
(median) & to 2007/08 & & & & & & \\
SID [m] & & & & & & & \\
\cline { 2 - 7 } & BSS, & $\mathbf{0 . 0 0}$ & -0.22 & 0.08 & -0.36 & -0.46 & -0.69 \\
& $03 / 2007$ & $\mathbf{( 0 . 0 1 )}$ & $(-0.24)$ & $(-0.15)$ & $(-0.33)$ & $(-0.40)$ & $(-0.70)$ \\
\hline
\end{tabular}

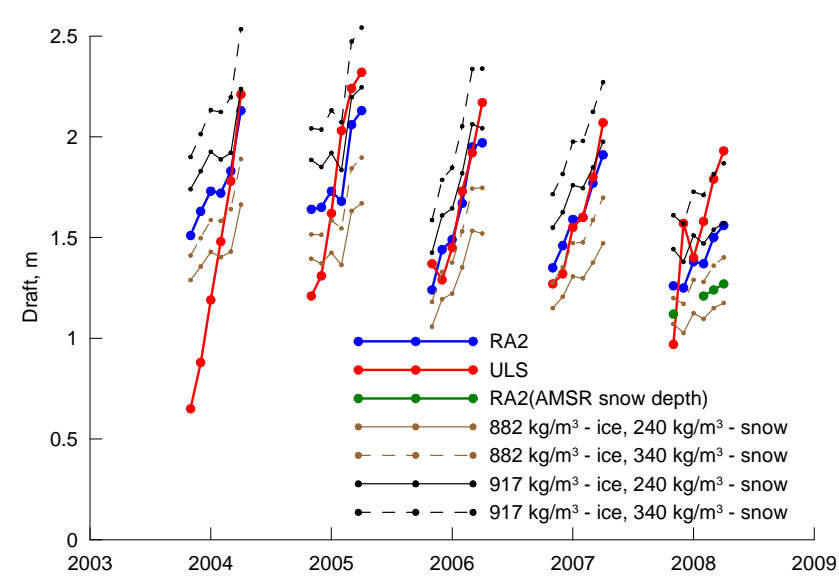

Figure 7. BGEP ULS draft data, averaged to monthly mean for the winter months October to March (red) compared to monthly mean draft computed from RA-2 sea ice freeboard using W99 snow depth and density and standard values: $\rho_{i}=900 \mathrm{~kg} \mathrm{~m}^{-3}$ and $\rho_{w}=1030 \mathrm{~kg} \mathrm{~m}^{-3}$ (blue); W99 snow depth but MYI density: $\rho_{i}=882 \mathrm{~kg} \mathrm{~m}^{-3}$ (brown); W99 snow depth and FYI density: $\rho_{i}=917 \mathrm{~kg} \mathrm{~m}^{-3}$ (black); and AMSR-E snow depth (green). Note that the latter is only possible for FYI areas. Snow density is set fixed to either $240 \mathrm{~kg} \mathrm{~m}^{-3}$ (solid lines) or $340 \mathrm{~kg} \mathrm{~m}^{-3}$ (broken lines) for the lines where sea ice density is varied (brown + black).

$290 \mathrm{~kg} \mathrm{~m}^{-3}$ (Fig. 7, green dots); these RA-2 ice drafts are much smaller than those observed by the ULS. However, as AMSR-E snow depth can only be obtained over FYI, the usage of MYI ice density and AMSR-E together may yield too small draft estimates, and one might need to use the FYI density of $917 \mathrm{~kg} \mathrm{~m}^{-3}$ instead. This would shift the green dots by $0.3 \mathrm{~m}$ towards larger ice draft values (Fig. 7, compare blue and black lines) and would result in a slightly better agreement between ULS and RA-2 drafts. More investigations are needed to confirm this.

Furthermore, we compared ULS sea ice draft with sea ice draft computed from RA sea ice freeboard using six different realizations of the freeboard-to-draft conversion. Of the six realizations, one uses fixed ice density at $900 \mathrm{~kg} \mathrm{~m}^{-3}$, i.e. the average of typical FYI and MYI densities, and W99 snow depth (A1); one uses separate FYI and MYI densities and parameterizes W99 snow depth following (Laxon et al., 2013) (A2); one uses fixed FYI density at $910 \mathrm{~kg} \mathrm{~m}^{-3}$ combined with a freeboard dependent MYI density (Ackley et al., 1974) and W99 snow depth (A3); one uses fixed ice density at $900 \mathrm{~kg} \mathrm{~m}^{-3}$ (see A1) with full and half W99 snow depth over FYI and MYI, respectively (A4); one uses separate but fixed FYI and MYI snow depth and separate FYI and MYI densities (Alexandrov et al., 2010) (A5); one follows the empirical approach for thick MYI without including any snow depth information (Wadhams et al., 1992) (A6). All realizations use seasonally varying W99 snow density. Of these realizations only A1 is shown in Figs. 6 and 7. Table 5 summarizes the difference in the mean and median observed minus computed sea ice draft (SID) for the six realizations and the ULS data sets listed in Table 1. Methods A1, A3 and A4 agree equally well with the ULS sea ice draft data within their uncertainty bounds (about $0.3 \mathrm{~m}$ for BS and BSS and 
$0.05 \mathrm{~m}$ for BGEP), and A5 and A6 show the largest discrepancies.

\subsection{Sea ice thickness}

We computed sea ice thickness from RA-2 data collocated with the OIB tracks in the Arctic Ocean (see Fig. 1) using different snow depth data and compared the results to OIB $(2009,2010)$ sea ice thickness estimates using the thicknesses provided in the OIB data set (Kurtz et al., 2013). For the RA-2 freeboard-to-thickness conversion, we used the sea ice density of $900 \mathrm{~kg} \mathrm{~m}^{-3}$. We omitted CryoVEx data from this comparison because of the ambiguous results reported in Sect. 4.2 and because W99 snow depth is less reliable in the area sensed during CryoVEx compared to the OIB track obtained in the Fram Strait in April 2010. Snow depth data sets used are W99 only, W99 over MYI and $0.5 \times$ W99 over FYI (Kurtz and Farrell (2011), henceforth abbreviated KF11), OIB only, and W99 over MYI, but AMSR-E over FYI. The results of this comparison are summarized in Table 6 for the OIB tracks from 2009 and 2010 in the Arctic Ocean and in Table 7 for the OIB track from 2010 in the Fram Strait.

For OIB 2009 data of the Arctic Ocean, none of the four snow data sets reveal a RA-2 sea ice thickness correlated with the OIB one better than 0.65. Using OIB snow depth gives highest correlation and smallest RMSD of $0.96 \mathrm{~m}$. However, the RMSD is similar for the other three data sets. For OIB 2010 data of the Arctic Ocean, using OIB snow depth gives highest correlation, 0.38, but largest RMSD, $1.52 \mathrm{~m}$ (Table 6). Correlations and RMSD are smaller when using the other snow data sets. Using W99 data results in the lowest correlation but also the smallest RMSD (Table 6). This is illustrated by Fig. 8 which shows scatterplots of sea ice thickness computed using the mentioned snow depth data sets versus observed sea ice thickness during OIB for 2009 (images a to c) and 2010 (images $d$ to f). Using W99 in combination with AMSR-E and KF11 results in a similar statistics because AMSR-E snow depth is found to be close to half the W99 snow depth and to agree with OIB snow depth within $0.02 \mathrm{~m}$ (see Table 2 and Kurtz and Farrell (2011)).

For the Fram Strait, OIB and RA-2 sea ice thickness agree well using either OIB 2010 or W99 snow depth data. The correlation between OIB and RA-2 are 0.84 (OIB 2010 snow) and 0.80 (W99 snow), see Table 7. Similar to the OIB tracks of 2010 in the Arctic Ocean (Table 6) the RMSD is smaller using W99 snow depth, $0.88 \mathrm{~m}$, than using OIB snow depth, $1.03 \mathrm{~m}$. The number of data points (only 13 data pairs; Fig. $8 \mathrm{~g}, \mathrm{~h}$ ) is, substantially smaller in this region than in the Arctic Ocean region, which limits the value of this comparison. Also the number of snow depth observations contributing to the W99 climatology is quite small in the Fram Strait area (see Warren et al., 1999), which might limit their usefulness for such a study in this area. However, the three boxes ( $5^{\circ}$ latitude by $15^{\circ}$ longitude) adjacent to the US and north- ern Canadian coast contain a similarly small amount of snow depth observations in W99: 50, 43, and 9 compared to 20,53, and 45 for the boxes north of Svalbard (Warren et al., 1999, Fig. 3).

\section{Discussion}

The present paper deals with an investigation of the quality and the usefulness of input parameters such as snow depth and densities of snow and sea ice for radar altimeter freeboard-to-thickness conversion. It further gives examples of inter-comparisons between independent estimates of sea ice parameters such as sea ice freeboard, total (sea ice + snow) freeboard, sea ice thickness and sea ice draft, and estimates of these parameters based on satellite radar altimetry. The evaluation of radar altimeter freeboard and the computation of a radar altimeter freeboard uncertainty are not aimed for in the present paper. We assume that the obtained sea ice freeboard is correct. For Envisat RA-2 data this is a fair assumption given the results of, e.g. Connor et al. (2009). An estimate of sea ice freeboard obtained by subtracting OIB snow depth from OIB total freeboard agrees within $0.02 \mathrm{~m}$ with colocated RA-2 sea ice freeboard. This is better than the accuracy of $0.05 \mathrm{~m}$ given for RA-2 and OIB freeboard data (Kurtz et al., 2013) and indicates that at least along OIB tracks in 2009 and 2010 in the Arctic Ocean, Envisat RA-2 sea ice freeboard is accurate.

Our main conclusion from the comparison of using different estimates for snow depth and ice density (see Table 5) is that methods A1, A3 and A4 agree equally well with the ULS sea ice draft data within their uncertainty bounds (about $0.3 \mathrm{~m}$ for BS and BSS and $0.05 \mathrm{~m}$ for BGEP), and that A5 and A6 show the largest discrepancies. Why is A2 (Laxon et al., 2013) biased low? Almost all ULS data are obtained under MYI. A2 uses a MY ice density of $882 \mathrm{~kg} \mathrm{~m}^{-3}$ while $\mathrm{A} 1$ and A4 use $900 \mathrm{~kg} \mathrm{~m}^{-3}$. Such a difference in sea ice density can cause a negative bias in the obtained sea ice draft by $0.2 \mathrm{~m}$ (compare blue and brown lines in Fig. 7). However, the good agreement between A1 and A4 in mean and median sea ice draft (Table 5) does not mean these use the perfect combination of input parameters. As we can see in Fig. 7 for A1, agreement between observed and computed sea ice draft varies from month to month. As stated in Sect. 4.3, RA-2 sea ice draft does not very well capture the increase in ULS sea ice draft over winter. Generally the increase in RA-2 sea ice draft is smaller than the increase in ULS sea ice draft. There could be various reasons for this.

The area covered by the BGEP moorings (A, B, C and D) is approximately $4^{\circ}$ in latitude by $10^{\circ}$ in longitude while RA-2 sea ice draft is computed from an area of $12^{\circ}$ in latitude by $30^{\circ}$ in longitude to account for ice type changes due to drift during the freezing season and to ensure a large enough number of single RA-2 freeboard measurements (confer Fig. 2). Hence RA-2 SID is an average over 
Table 6. Summary of comparison between RA-2 sea ice thickness computed using different snow depth data sets and OIB sea ice thickness for the Arctic Ocean. Total number of data pairs is $N=43$ for 2009 and $N=90$ for 2010.

\begin{tabular}{l|cccc|cccc}
\hline month/year & \multicolumn{4}{|c|}{$04 / 2009$} & \multicolumn{4}{c}{$03+04 / 2010$} \\
\hline \multirow{2}{*}{ Snow data set } & OIB & W99 & +W99 & KF11 & OIB & W99 & +W99 & KF11 \\
\hline $\mathrm{R}$ & 0.65 & 0.57 & 0.62 & 0.62 & 0.38 & 0.23 & 0.34 & 0.34 \\
\hline RMSD [m] & 0.96 & 1.00 & 1.02 & 1.02 & 1.52 & 1.35 & 1.41 & 1.40 \\
\hline
\end{tabular}
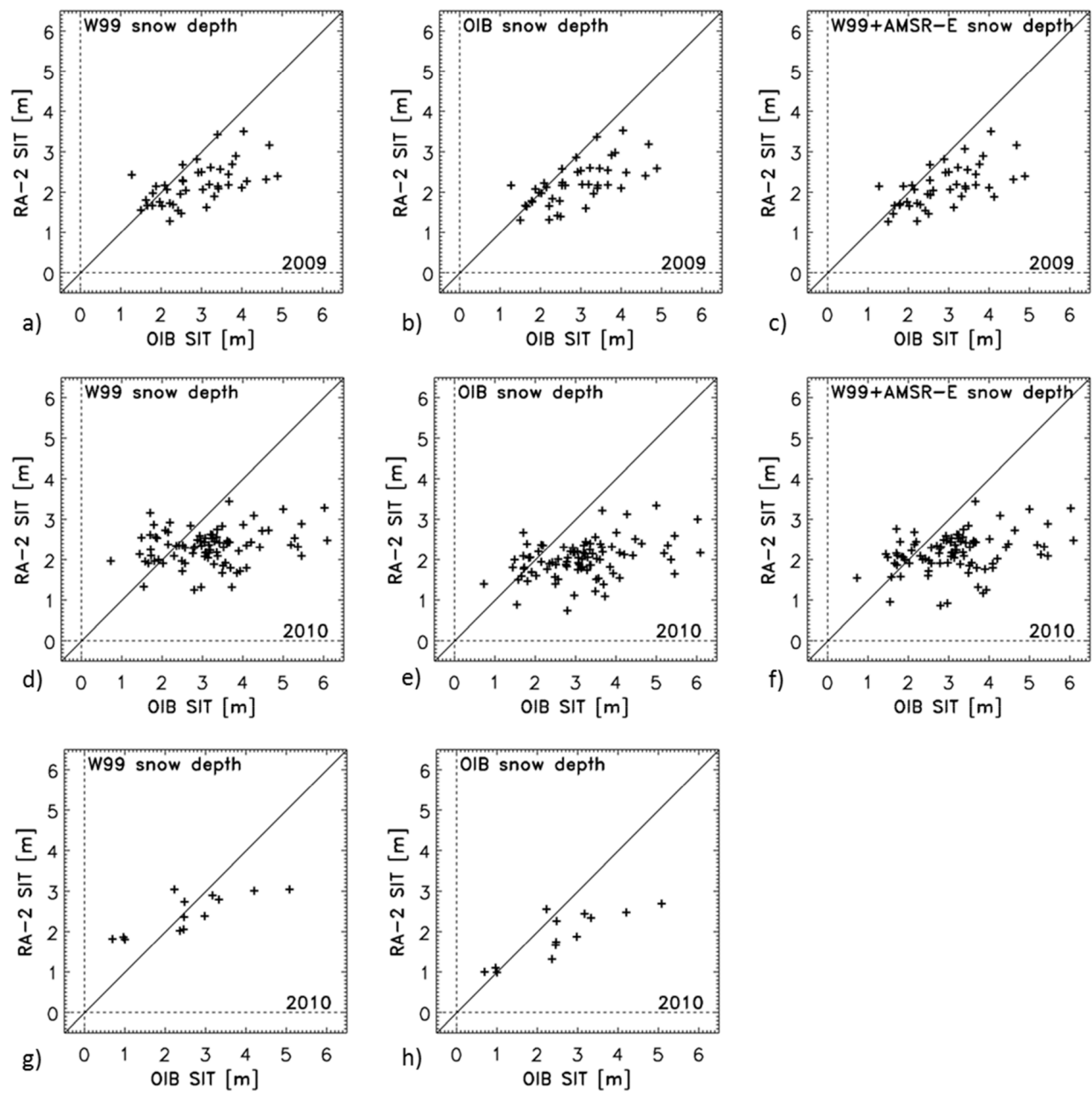

Figure 8. RA-2 sea ice thickness computed using different snow depth data sets versus OIB sea ice thickness for 2009 (a to c) and 2010 $(\mathbf{d}$ to $\mathbf{h})$. Images (a) to (f) are for the Arctic Ocean, images (g) and (h) are for the Fram Strait area.

an almost 10-fold larger area which can explain the smaller seasonal amplitude.

Freeboard-to-thickness conversion is very sensitive to the correct choice of snow depth (see, e.g. Zygmuntowska et al. (2014) and Fig. 9b). We found that W99 snow depth is twice as large as OIB snow depth over FYI, as already reported by Kurtz and Farrell (2011) and Kurtz et al. (2013). AMSR-E snow depths over FYI agree with OIB snow depth within $0.02 \mathrm{~m}$. We find that even over MYI W99 might overestimate the actual snow depth, as is the case for April 2010. The climatological nature of W99 on the one hand and interannual variation of snow depth on the other hand explain part of the disagreement, but more snow depth inter-comparisons are required to further investigate this finding. It was shown recently that Soil Moisture and Ocean Salinity (SMOS) satellite data can be used to retrieve snow depth over thick Arctic 
Table 7. Summary of comparison between RA-2 sea ice thickness computed using different snow depth data sets and OIB sea ice thickness for the Fram Strait area for April 2010. Total number of data pairs is $N=13$.

\begin{tabular}{lcc}
\hline Snow data set & $\mathrm{R}$ & $\mathrm{RMSD}[\mathrm{m}]$ \\
\hline W99 & 0.80 & 0.88 \\
OIB & 0.84 & 1.03 \\
\hline
\end{tabular}

sea ice, e.g. MYI (Maaß et al., 2013). Such data could be combined with snow depth from an AMSR-E sensor type of product. For this, however, a better quantification of the MYI fraction than is included in the AMSR-E snow depth product (Cavalieri et al., 2004) is mandatory. This would not only help to obtain a more realistic snow depth distribution but it would also help to choose correct sea ice densities (see below). For this purpose, we recommend carrying out an intercomparison of current sea ice type data sets in the Arctic as can be derived, for example, from satellite scatterometry e.g. QuikSCAT (Kwok, 2004; Swan and Long, 2012). For the Envisat RA-2 measurement period QuikSCAT products can be used. However, for the planned sea ice thickness data set for 1993 until the present, a harmonized sea ice type distribution data set needs to be developed, which is free of inconsistencies or biases due to changes between sensors, such as from ERS1/2 ESCAT to QuikSCAT to ASCAT.

We find that typical variations in sea ice density cause variations in sea ice thickness that are as large as those caused by snow depth variations. This is different to laser altimetry (Kwok and Cunningham, 2008). Under typical variations we understand the difference between MYI and FYI densities (Alexandrov et al., 2010) and the difference between snow depth on MYI compared to FYI (see Table 2). For typical sea ice freeboard values, the typical range in ice density induces variations in sea ice thickness between $0.4 \mathrm{~m}$ and $0.8 \mathrm{~m}$ (see Fig. 9a). Hence the freeboard-to-thickness conversion is quite sensitive to the choice of sea ice density. Consequently, CryoSat-2 sea ice thickness retrieval (Laxon et al., 2013) uses two different sea ice densities - one for FYI and one for MYI. The sensitivity due to sea ice density can be seen in Fig. 7, which shows differences of up to $0.7 \mathrm{~m}$ (March 2004 and March 2005) between RA-2 sea ice draft calculated using a typical FYI density (black lines) and a typical MYI density (brown lines).

We did not carry out a detailed investigation of the impact of snow density. According to the W99 climatology and other studies, e.g. Alexandrov et al. (2010), snow density varies seasonally between $<100 \mathrm{~kg} \mathrm{~m}^{-3}$ (fresh snow) to $>400 \mathrm{~kg} \mathrm{~m}^{-3}$ (old, compacted snow). Snow density can also vary on short spatial scales. However, in this study satellite RA data is used to obtain sea ice thickness at $100 \mathrm{~km} \mathrm{spa-}$ tial scale and a temporal scale of a month. Therefore we feel confident in referring to Fig. 7 to illustrate the effect of

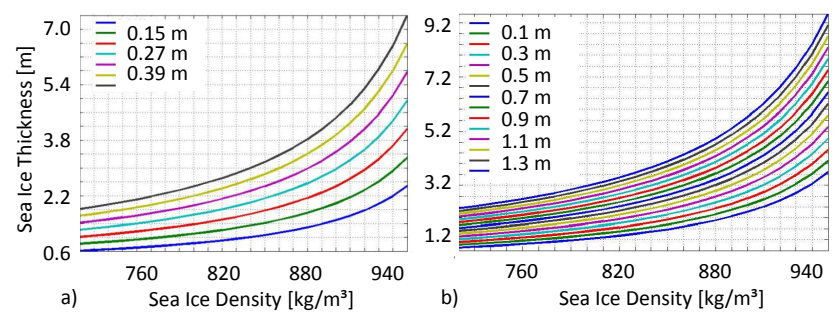

Figure 9. Sensitivity of sea ice thickness obtained from RA sea ice freeboard sea ice density and snow depth. (a) Sea ice thickness computed with Eq. (1) for different sea ice freeboard values $(0.009 \mathrm{~m}$ to $0.45 \mathrm{~m}$ ) and snow depth $0.3 \mathrm{~m}$ as function of sea ice density. (b) Similar to (a) but computed for different snow depths ( $0 \mathrm{~m}$ to $1.4 \mathrm{~m})$ and sea ice freeboard $0.27 \mathrm{~m}$ as function of sea ice density.

snow density. Snow densities range typically over values of $240 \mathrm{~kg} \mathrm{~m}^{-3}$ to $340 \mathrm{~kg} \mathrm{~m}^{-3}$. The change in mean sea ice draft associated with the snow density range applied is about $0.2 \mathrm{~m}$ to $0.3 \mathrm{~m}$. This translates into a bias in sea ice thickness of a magnitude of $0.3 \mathrm{~m}$ and recommends using seasonally varying snow density when retrieving ice thickness from satellite RA data as is done in this paper.

It is important to bear in mind the different spatiotemporal scales which are involved. For instance, OIB data is obtained at fine spatiotemporal resolution along transects and is averaged over $50 \mathrm{~km}$ long segments for this study (see Sect. 2). RA-2 data, as are used here, comprise measurements from all overpasses within a month which fall into a disc of $100 \mathrm{~km}$ diameter centred at each $50 \mathrm{~km}$ OIB track segment. In addition the footprint of a single RA-2 measurement is 2 to 3 orders of magnitude larger than the footprint of a single OIB measurement. It is likely that RA-2 data provide an average ice thickness rather than the actual range of ice thickness values (see Fig. 8). This depends, however, on the degree by which different ice types and ice surface properties impact the radar backscatter and the waveform (Zygmuntowska et al., 2013, Ricker et al., 2014). More studies need to look into the different backscatter of sea ice of different types and roughness to quantify the impact of sea ice property variation on the radar altimeter signal and hence the sea ice freeboard.

OIB sea ice thickness is computed using a fixed sea ice density of $915 \mathrm{~kg} \mathrm{~m}^{-3}$ (Kurtz et al., 2013). This density value represents FYI but results in a positive bias in draft and thickness for MYI because it is about $30 \mathrm{~kg} \mathrm{~m}^{-3}$ higher than the average MYI density value suggested, e.g. by Alexandrov et al. (2010). This makes an assessment of the obtained sea ice thickness values a difficult task, in particular if the aim is to quantify the impact of different sea ice density values on the obtained sea ice thickness. Currently, OIB data are the only airborne data source for contemporary data of freeboard and snow depth.

Our interpretation of the CryoVEx data remains inconclusive because the ASIRAS instrument, which is supposed to sense the ice-snow interface and thus provide an inde- 
pendent sea ice freeboard measurement, failed to do so. Instead it provided the total freeboard as does the ALS sensor. By means of atmospheric re-analysis data, we identify snow cover property changes as a possible reason for CryoVEx 2011 but not for 2008. This suggests that even under freezing conditions sensors such as Envisat RA-2 or CryoSat-2 might not sense the sea ice surface. It is likely that vertical snow density gradients and/or volume scattering in the snow in general influence the radar signal, resulting in a less distinct signal from the ice-snow interface or in similarly strong returns from the snow surface or interior as was shown for Antarctic sea ice by Willatt et al. (2010).

We note that almost all sea ice draft data and many of our validation data are from MYI regions. A real assessment of approaches which includes ice-type dependent ice density and snow depth could therefore not be carried out in a systematic enough way. More work and more data are required here.

\section{Summary and recommendations}

Satellite radar altimetry (RA) has been providing surface elevation measurements of the Arctic Ocean for about 2 decades. With the assumption that these elevation measurements represent sea ice freeboard these are used to derive sea ice thickness (Laxon et al., 2013, 2003). Here we report on the results of an investigation of the sensitivity of satellite RA freeboard-to-thickness conversion to input parameters and assumptions carried out within the European Space Agency Climate Change Initiative Sea Ice Essential Climate Variable project using Envisat radar altimetry (RA-2). For RA sea ice freeboard uncertainty estimation, which is not part of the present paper, we refer to, e.g. Peacock and Laxon (2004); Zygmuntowska et al. (2013); Ricker et al. (2014); Kurtz et al. (2014) and Armitage and Davidson (2014).

We found the Warren snow depth climatology (W99, Warren et al., 1999) to be outdated, in agreement with earlier studies (Kwok et al., 2011; Kurtz and Farrell, 2011). Modal and mean sea ice draft computed from RA-2 sea ice freeboard using different realizations of the freeboard-to-draft conversion agree with upward looking sonar observations of the freezing season (October to March) sea ice draft in the Beaufort Sea within the uncertainty bounds - provided the realizations include spatiotemporally varying snow depth and density. However, none of the realizations are able to reproduce the seasonal range in sea ice draft. A change of sea ice densities and/or snow depths as a function of ice type can improve the agreement with observed sea ice draft values at the beginning or end of the freezing season but does not have an impact on the overall seasonal sea ice draft range obtained from RA-2 data. Sea ice thickness computed from RA-2 sea ice freeboard using different snow depth data sets overestimate (underestimate) small (large) OIB sea ice thickness. An improvement from using ice-type-dependent snow depth is not evident in our results, but most likely this simply needs more data and a different inter-comparison strategy to be quantified.

Some of the independent data used in our study point towards a larger range in sea ice draft and thickness than observed by RA-2. This results from the impact of different ground resolutions of the compared sensors. Submarine and airborne sensors have a much finer sampling of the sea ice along their track; sampling by RA is coarser and in addition depends on floe size, lead concentration, waveform distortion and surface roughness. Averaging over a track length of $50 \mathrm{~km}$ or $100 \mathrm{~km}$ of a submarine or an airborne sensor can only be an approximation of the variability in sea ice freeboard obtained from RA-2 over a disc with diameter $100 \mathrm{~km}$. Data from submarine and airborne campaigns cover a few days while RA-2 data are averages over a month. More emphasis needs to be put on the choice of the scales involved both for sea ice thickness computation and validation. Hence, for a better validation of both sea ice freeboard and thickness products at a spatiotemporal scale of $100 \mathrm{~km}$ and one month, more data from airborne campaigns are required. Data from airborne campaigns, which allow sea ice thickness retrieval, often suffer from (i) environmental conditions and their not yet fully known impact on snow and sea ice physical properties (see our results from CryoVEx 2008 and 2011); (ii) uncertainty sources are not yet well understood (Kurtz et al., 2013); (iii) assumptions and parameters, such as sea ice and snow densities, used for derivation of sea ice thickness or snow from airborne data may differ from campaign to campaign and to spaceborne data, and may not be state of the art in view of recent literature (e.g. Alexandrov et al., 2010; Laxon et al., 2013).

We formulate the following recommendations for freeboard-to-thickness conversion using radar altimetry for the Arctic Ocean:

1. The Warren climatology has to be used carefully. It is not valid over first-year ice and it is of limited use outside the central Arctic Ocean. The Warren climatology is still valuable when no other depth snow estimate is available but we recommend using the Warren climatology in combination with a second data set of snow depth over first-year ice. Furthermore we recommend that effort should be put into developing an inter-annually varying snow depth and density over sea ice product for the ice-covered oceans. Snow depth obtained from SMOS over thick sea ice might be an important contribution here (Maaß et al., 2013).

2. Using radar altimetry, the impact of sea ice density on sea ice thickness retrieval is as large as the impact of snow depth. The difference in sea ice densities of multiyear ice and first-year ice is large enough to explain a bias in sea ice thickness of the magnitude of $0.5 \mathrm{~m}$ or more. It is recommended to use an ice-type dependent set of sea ice densities. In addition it is important to 
also consider the density difference between ridged and level ice. We need many more measurements of ice density and isostasy across first-year ice and multiyear ice ridges to derive area-averaged ice densities for ridged sea ice.

3. For a sophisticated inter-comparison and validation of the final sea ice thickness product from satellite altimetry it is mandatory to use independent and preferably non-altimetric validation data. The amount of such contemporary sea ice draft, snow depth and sea ice thickness data is clearly sub-optimal and needs to be improved.

4. Potential improvement from utilizing new sets of input parameters, e.g. densities, cannot be quantified without consistent input parameters for freeboard-to-thickness conversion. We call for a consistent internationally agreed-upon standard set of densities to be used for freeboard-to-thickness conversion to be applied to airand spaceborne altimeter data.

Author contributions. S. Kern prepared the manuscript with contributions from all co-authors but mainly E. Rinne, prepared Figs. 1, 2, and 8, and supervised Z. S. Parsakhoo. K. Khvorostovsky contributed a large part of the data analysis of the ULS data, namely Figs. 5, 6, and 7. H. Skourup was responsible for the analysis and interpretation of CryoVEx data and prepared Fig. 4. E. Rinne was responsible for the Round Robin Data Package, contributed substantially with writing and prepared Figs. 3 and 6e. Z. S. Parsakhoo was responsible for the inter-comparison of the snow depth data. V. Djepa prepared Fig. 9. P. Wadhams contributed with the scientific supervision of V. Djepa. S. Sandven contributed with the overall scientific supervision, in particular of K. Khvorostovsky.

Acknowledgements. This work was funded by ESA/ESRIN (sea ice CCI). S. Kern acknowledges support from the Center of Excellence for Climate System Analysis and Prediction (CliSAP), University of Hamburg, Germany. This work is also supported by the Research Council of Norway under contract no. 207584 (ArcticSIV). We are grateful to numerous data providers for the present study, namely, National Snow and Ice Data Centre (NSIDC) for OIB data, AMSR-E snow depth, SSM/I and AMSR-E sea ice concentrations, and the US submarine ULS data; Woods Hole Oceanographic Institute for BGEP ULS data; ESA for re-processed ERS-1/2 and Envisat ASAR data. The authors are grateful to all the teams in the field, in the air and in the ship for providing all these valuable observations. S. Kern acknowledges support from the International Space Science Institute (ISSI), Bern, Switzerland, under project no. 245: Heil, P. and Kern, S. "Towards an Integrated Retrieval of Antarctic Sea Ice Volume". We thank three anonymous reviewers and our editor Julienne Stroeve for their efforts to improve the paper.

Edited by: J. Stroeve

\section{References}

Ackley, S. F., Hibler III, W. D., Kugzruk, F., Kovacs, A., and Weeks, W. F.: Thickness and roughness variations of Arctic multiyear sea ice, AIDJEX Bulletin, 25, 75-95, 1974.

Alexandrov, V., Sandven, S., Wahlin, J., and Johannessen, O. M.: The relation between sea ice thickness and freeboard in the Arctic, The Cryosphere, 4, 373-380, doi:10.5194/tc-4-373-2010, 2010.

Armitage, T. W. K. and Davidson, M. W. J.: Using the interferometric capabilities of the ESA Cryosat- 2 mission to improve the accuracy of sea ice freeboard retrievals, Trans. Geosci. Rem. Sens., 51, 529-536, doi:10.1109/TGRS.2013.2242082, 2014.

Bröhan, D. and Kaleschke L.: A nine-year climatology of Arctic sea ice lead orientation and frequency from AMSR-E, Remote Sens., 6, 1451-1475, doi:10.3390/rs6021451, 2014.

Brucker, L. and Markus, T.: Arctic-scale assessment of satellite passive microwave derived snow depth on sea ice using operational icebridge airborne data, J. Geophys. Res.-Oceans, 118, 28922905, doi:10.1002/jgrc.20228, 2013.

Cavalieri, D. J., Markus, T., and Comiso, J. C.: AMSR-E/Aqua Daily L3 25 km Brightness Temperature \& Sea Ice Concentration Polar Grids Version 2, Boulder, Colorado USA: NASA DAAC at the National Snow and Ice Data Center, 2004.

Cavalieri, D. J., Markus, T., Ivanoff, A., Miller, J. A., Brucker, L., Sturm, M., Maslanik, J., Heinrichs, J. F., Gasiewski, A. J., Leuschen, C., Krabill, W., and Sonntag, J.: A comparison of snow depth on sea ice retrievals using airborne altimeters and an AMSR-E Simulator, Trans. Geosci. Rem. Sens., 50, 3027-3040, 2012.

Comiso, J. C., Cavalieri, D. J., and Markus, T.: Sea ice concentration, ice temperature and snow depth using AMSR-E data, Trans. Geosci. Rem. Sens., 41, 243-252, 2003.

Connor, L. N., Laxon, S. W., Ridout, A. L., Krabill, W., and McAdoo, D.: Comparison of Envisat radar and airborne laser altimeter measurements over Arctic sea ice, Remote Sens. Environ., 113, 563-570, 2009.

ESA SICCI project consortium: D2.6: Algorithm Theoretical Basis Document (ATBDv1), ESA Sea Ice Climate Initiative Phase 1 Report SICCI-ATBDv1-04-13, version 1.1, 2013.

Farrell, S. L., Kurtz, N. T., Connor, L., Elder, B., Leuschen, C., Markus, T., McAdoo, D. C., Panzer, B., Richter-Menge, J., and Sonntag, J.: A first assessment of icebridge snow and ice thickness data over Arctic Sea Ice, Trans. Geosci. Rem. Sens., 50, 6, 2098-2111, 2012.

Giles, K. A. and Hvidegaard, S. M.: Comparison of space borne radar altimetry and airborne laser altimetry over sea ice in the Fram Strait, Int. J. Remote Sens., 27, 3105-3113, 2006.

Giles, K. A., Laxon, S. W., Wingham, D. J., Wallis, D. W., Krabill, W. B., Leuschen, C. J., McAdoo, D., Manizade, S. S., and Raney, R. K.: Combined airborne laser and radar altimeter measurements over the Fram Strait in May 2002, Remote Sens. Environ., 111, 182-194, 2007.

Giles, K. A., Laxon, S. W., and Ridout, A. L.: Circumpolar thinning of Arctic sea ice following the 2007 record ice extent minimum, Geophys. Res. Lett., 35, L22502, doi:10.1029/2008GL035710, 2008.

Haas, C., Pfaffling, A., Hendricks, S., Rabenstein, L., Etienne, J.L., and Rigor, I.: Reduced ice thickness in Arctic Transpolar 
Drift favours rapid ice retreat, Geophys. Res. Lett., 35, L17501, doi:10.1029/2008GL034457, 2008.

Haas, C., Hendricks, S., Eicken, H., and Herber, A.: Synoptic airborne thickness surveys reveal state of Arctic sea ice cover, Geophys. Res. Lett., 37, L09501, doi:10.1029/2010GL042652, 2010.

Hvidegaard, S. M. and Forsberg, R.: Sea ice thickness from laser altimetry over the Arctic Ocean north of Greenland, Geophys. Res. Lett., 29, 1952-1955, 2002.

Kaleschke, L., Tian-Kunze, X., Maßß, N., Mäkynen, M., and Drusch, M.: Sea ice thickness retrieval from SMOS brightness temperatures during the Arctic freeze-up period, Geophys. Res. Lett., 39, L05501, doi:10.1029/2012GL050916, 2012.

Kern, S., Ozsoy-Cicek, B., Willmes, S., Nicolaus, M., Haas, C., and Ackley, S. F.: An intercomparison between AMSR-E snow depth and satellite $\mathrm{C}$ - and $\mathrm{Ku}-\mathrm{Band}$ radar backscatter data for Antarctic sea ice, Ann. Glaciol., 52, 279-290, 2011.

Krinner, G., Rinke, A., Dethloff, K., and Gorodetskaya, I. V.: Impact of prescribed Arctic sea ice thickness in simulations of the present and future climate, Clim. Dynam., 35, 619-633, doi:10.1007/s00382-009-0587-7, 2010.

Krishfield, R. and Proshutinky, A.: BGOS ULS Data Processing Procedure Report Woods Hole Oceanographic Institute, available at: http://www.whoi.edu/fileserver.do?id=85684\&pt=2\&p= 100409 (last access: 25 January 2014), 2006.

Kurtz, N. T. and Farrell, S. F.: Large-scale surveys of snow depth on Arctic sea ice from Operation IceBridge, Geophys. Res. Lett., 38, L20505, doi:10.1029/2011GL049216, 2011.

Kurtz, N. T., Farrell, S. L., Studinger, M., Galin, N., Harbeck, J. P., Lindsay, R., Onana, V. D., Panzer, B., and Sonntag, J. G.: Sea ice thickness, freeboard, and snow depth products from Operation IceBridge airborne data, The Cryosphere, 7, 1035-1056, doi:10.5194/tc-7-1035-2013, 2013.

Kurtz, N. T., Galin, N., and Studinger, M.: An improved CryoSat-2 sea ice freeboard retrieval algorithm through the use of waveform fitting, The Cryosphere, 8, 1217-1237, doi:10.5194/tc-8-12172014, 2014.

Kwok, R.: Annual cycles of multiyear sea ice coverage of the Arctic Ocean: 1999-2003, J. Geophys. Res., 109, C11004, doi:10.1029/ 2003JC002238, 2004.

Kwok, R. and Cunningham, G. F.: ICESat over Arctic sea ice: estimation of snow depth and ice thickness, J. Geophys. Res., 113, C08010, doi:10.1029/2008JC004753, 2008.

Kwok, R. and Maksym, T.: Snow depth of the Weddell and Bellingshausen sea ice covers from IceBridge surveys in 2010 and 2011: An examination, J. Geophys. Res.-Oceans, 119, doi:10.1002/2014JC009943, 2014.

Kwok, R., Nghiem, S. V., Yueh, S. H., and Huynh, D. D.: Retrieval of thin ice thickness from Multifrequency Polarimetric SAR data, Remote Sens. Environ., 51, 361-374, 1995.

Kwok, R., Cunningham, G. F., Wensnahan, M., Rigor, I., Zwally, H. J., and Yi, D.: Thinning and volume loss of the Arctic Ocean sea ice cover: 2003-2008, J. Geophys. Res., 114, C07005, doi:10.1029/2009JC005312, 2009.

Kwok, R., Panzer, B., Leuschen, C., Pang, S., Markus, T., Holt, B., and Gogineni, S. P.: Airborne surveys of snow depth over Arctic sea ice, J. Geophys. Res., 116, C11018, doi:10.1029/2011JC007371, 2011.

Kwok, R., Cunningham, G. F., Manizade, S. S., and Krabill, W. B.: Arctic sea ice freeboard from IceBridge acquisitions in 2009: estimates and comparisons with ICESat, J. Geophys. Res., 117, C02018, doi:10.1029/2011JC007654, 2012.

Laxon, S., Peacock, N., and Smith, D.: High interannual variability of sea-ice thickness in the Arctic region, Nature, 425, 947-950, 2003.

Laxon, S. W., Giles, K. A., Ridout, A. L., Wingham, D. J., Willatt, R., Cullen, R., Kwok, R., Schweiger, A., Zhang, J., Haas, C., Hendricks, S., Krishfield, R., Kurtz, N., Farrell, S. L., and Davidson, M.: CryoSat-2 estimates of Arctic sea ice thickness and volume, Geophys. Res. Lett., 40, 1-6, 2013.

Lindsay, R.: New unified sea ice thickness climate data record, EOS, 91, 405-406, 2010.

Maaß, N., Kaleschke, L., Tian-Kunze, X., and Drusch, M.: Snow thickness retrieval over thick Arctic sea ice using SMOS satellite data, The Cryosphere, 7, 1971-1989, doi:10.5194/tc-7-19712013, 2013.

Maksym, T. and Markus, T.: Antarctic sea ice thickness and snow-to-ice conversion from atmospheric reanalysis and passive microwave snow depth, J. Geophys. Res., 113, C02S12, doi:10.1029/2006JC004085, 2008.

Markus, T. and Cavalieri, D. J.: Snow depth distribution over sea ice in the southern ocean from satellite passive microwave data, in: Antarctic Sea Ice: Physical Processes, Interactions, and Variability, edited by: Jeffries, M. O., AGU Antarctic Research Series, American Geophysical Union, Washington DC, 74, 19-39, 1998.

Martin, S., Drucker, R., Kwok, R., and Holt, B.: Estimation of the thin ice thickness and heat flux for the Chukchi Sea Alaskan coast polynya from Special Sensor Microwave/Imager data, 1990-2001, J. Geophys. Res., 109, C10012, doi:10.1029/2004JC002428, 2004.

Onana, V.-de-P., Kurtz, N. T., Farrell, S. L., Koenig, L. S., Studinger, M., and Harbeck, J. P.: A sea-ice lead detection algorithm for use with high-resolution airborne visible imagery, Trans. Geosci. Rem. Sens., 51, 38-56, 2013.

Ozsoy-Cicek, B., Kern, S., Ackley, S. F., Xie, H., and Tekeli, A. E.: Intercomparisons of Antarctic sea ice types from visual ship, RADARSAT-1 SAR, Envisat ASAR, QuikSCAT, and AMSR-E satellite observations in the Bellingshausen Sea, Deep-Sea Res. Pt. II, 58, 9-10, 1092-1111, doi:10.1016/j.dsr2.2010.10.031, 2011.

Panzer, B., Gomez-Garcia, D., Leuschen, C., Paden, J., RodriguezMorales, F., Patel, A., Markus, T., Holt, B., and Gogineni, S. P. An ultra-wideband, microwave radar for measuring snow thickness on sea ice and mapping near-surface internal layers in polar firn, J. Glaciol., 59, 244-255, 2013.

Peacock, N. R. and Laxon, S. W.: Sea surface height determination in the Arctic Ocean from ERS altimetry, J. Geophys. Res., 109, C07001, doi:10.1029/2001JC001026, 2004.

Ricker, R., Hendricks, S., Helm, V., Gerdes, R., and Skourup, H.: Comparison of sea-ice freeboard distribution from aircraft data and CryoSat-2, Proceedings paper, 20 years of progress in radar altimetry, 24-29 September 2012, Venice, Italy, 2012.

Ricker, R., Hendricks, S., Helm, V., Skourup, H., and Davidson, M.: Sensitivity of CryoSat-2 Arctic sea-ice freeboard and thickness on radar-waveform interpretation, The Cryosphere, 8, 16071622, doi:10.5194/tc-8-1607-2014, 2014. 
Rothrock, D. A. and Wensnahan, M.: The accuracy of sea-ice drafts measured from US Navy submarines, J. Atmos. Ocean Tech., 24, 1936-1949, doi:10.1175/JTECH2097.1, 2007.

Rothrock, D. A., Percival, D. B., and Wensnahan, M.: The decline in arctic sea-ice thickness: separating the spatial, annual, and interannual variability in a quarter century of submarine data, J. Geophys. Res., 113, C05003, doi:10.1029/2007JC004252, 2008.

Schweiger, A., Lindsay, R., Zhang, J., Steele, M., Stern, H., and Kwok, R.: Uncertainty in modeled Arctic sea ice volume, J. Geophys. Res., 116, C00D06, doi:10.1029/2011JC007084, 2011.

Spreen, G., Kern, S., Stammer, D., Forsberg, R., and Haarpaintner, J.: Satellite based estimation of sea ice volume flux through Fram Strait, Ann. Glaciol., 44, 321-328, 2006.

Stranne, C. and Björk, G.: On the Arctic Ocean ice thickness response to changes in external forcing, Clim. Dynam., 39, 30073018, doi:10.1007/s00382-011-1275-y, 2012.

Swan, A. M. and Long, D. G.: Multiyear Arctic sea ice classification using QuikSCAT, Trans. Geosci. Rem. Sens., 50, 9, 3317-3326, doi:10.1109/TGRS.2012.2184123, 2012.

Timco, G. W. and Frederking, R. M. W.: A review of sea ice density, Cold Reg. Sci. Technol., 24, 1-6, 1996.

Wadhams, P.: Arctic ice cover, ice thickness and tipping points, Ambio, 41, 23-33, 2012.

Wadhams, P., Tucker III, W. B., Krabill, W. B., Swift, R. N., Comiso, J. C., and Davis, N. R.: Relationship between sea ice freeboard and draft in the Arctic Basin, and implications for ice thickness monitoring, J. Geophys. Res., 97, 20325-20334, doi:10.1029/92JC02014, 1992.

Wadhams, P., Hughes, N., and Rodrigues, J.: Arctic sea ice thickness characteristics in winter 2004 and 2007 from submarine sonar transects, J. Geophys. Res., 116, C00E02, doi:10.1029/2011JC006982, 2011.
Warren, S. G., Rigor, I. G., Untersteiner, N., Radionov, V. F., Bryazgin, N. N., Aleksandrov, Y. I., and Colony, R.: Snow depth on Arctic sea ice, J. Climate, 12, 1814-1829, 1999.

Willatt, R. C., Giles, K. A., Laxon, S. W., Stone-Drake, L., and Worby, A. P.: Field investigations of Ku-Band radar penetration into snow cover on Antarctic sea ice, Trans. Geosci. Rem. Sens. 48, 365-372, doi:10.1109/TGRS.2009.2028237, 2010.

Worby, A. P., Markus, T., Steer, A. D., Lytle, V. I., and Massom, R. A.: Evaluation of AMSR-E snow depth product over East Antarctic sea ice using in situ measurements and aerial photography, J. Geophys. Res., 113, C05S94, doi:10.1029/2007JC004181, 2008.

Yu, Y. and Rothrock, D. A.: Thin ice thickness from satellite thermal imagery, J. Geophys. Res., 101, 25753-25766, 1996.

Zhang, J., Lindsay, R., Schweiger, A., and Rigor, I. G.: Recent changes in the dynamic properties of declining Arctic sea ice: a model study, Geophys. Res. Lett., 39, L20503, doi:10.1029/2012GL053545, 2012.

Zygmuntowska, M., Khvorostovsky, K., Helm, V., and Sandven, S.: Waveform classification of airborne synthetic aperture radar altimeter over Arctic sea ice, The Cryosphere, 7, 1315-1324, doi:10.5194/tc-7-1315-2013, 2013.

Zygmuntowska, M., Rampal, P., Ivanova, N., and Smedsrud, L. H.: Uncertainties in Arctic sea ice thickness and volume: new estimates and implications for trends, The Cryosphere, 8, 705-720, doi:10.5194/tc-8-705-2014, 2014. 